
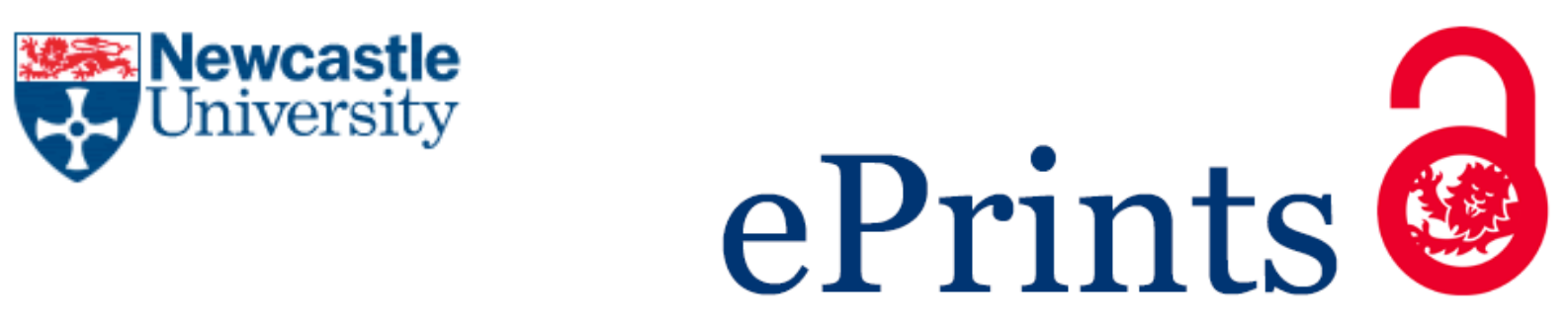

Rao-Nicholson R, Salaber J, Cao TH. Long-term performance of mergers and acquisitions in ASEAN countries. Research in International Business and Finance 2016, 36, 373-387.

Copyright:

(C) 2016. This manuscript version is made available under the CC-BY-NC-ND 4.0 license

DOI link to article:

http://dx.doi.org/10.1016/j.ribaf.2015.09.024

Date deposited:

$13 / 10 / 2016$

Embargo release date:

28 March 2017

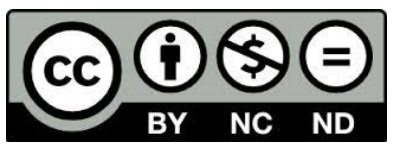

This work is licensed under a

Creative Commons Attribution-NonCommercial-NoDerivatives 4.0 International licence 


\title{
Long-Term Performance of Mergers and Acquisitions in ASEAN Countries
}

\section{Rekha Rao-Nicholson, Julie Salaber and Tuan Hiep Cao}

\begin{abstract}
The study looks at mergers and acquisitions (M\&As) in ASEAN countries and examines the post-M\&A performance using data from 2001 to 2012. The industry-adjusted operating performance tends to decline in the 3 years following an M\&A. Yet, the results suggest that M\&As completed during the financial crisis are more profitable than those implemented before and/or after the crisis. We argue that this is mainly due to the synergies created between the firms' resources during the crisis which augur well for firms' economic performance. We find that, during the crisis, certain characteristics of the firms like the relative size of the target, cross-border nature of deals, acquirer's cash reserves and friendly nature of deals are important determinants of long-term post-M\&A operating performance. However, for M\&As during the crisis, there appears to be no relationship between performance and firms' characteristics linked to M\&A activity such as payment method, industry relatedness and percentage of target's share acquired.
\end{abstract}

Keywords: Mergers and acquisitions, ASEAN, operating performance, financial crisis 


\section{Introduction}

In this paper, we focus on intra-regional mergers and acquisitions (M\&As) in the ASEAN (Association of Southeast Asian Nations) region. We investigate the determinants of post-M\&A performance of companies in this region and examine the impact of the recent global crisis. Developed markets experienced a gloomy economic growth as a consequence of the 2007-2008 financial crisis. Though the 1997-1999 Asian crisis had a profound impact on the ASEAN region (Sufian, 2009) and intra-regional flows decreased after 1997 (Rammal \& Zurbruegg, 2006), Asian countries continued to grow robustly after the 2007-2008 crisis (Economist, 2009). With a stable and high growth rate plus a dynamic business environment, ASEAN has emerged to be a promising destination for international investors (UNCTAD, 2012). Authors have suggested that, at regional level, trade agreements attempt to promote cross-border trade (Sufian \& Habibullah, 2012). In the early 1990s, M\&As were still relatively uncommon in Asia as these firms tend to emphasize internal development (Mitchell \& Shaver, 2002) and the M\&A market was at an early stage of development with a total value of $\$ 15$ billion (Metwalli \& Tang, 2009). The creation of ASEAN has gradually integrated the countries within this region. For example, Vietnam's joining of ASEAN has impacted positively its bilateral trade within the region (Anwar \& Nguyen, 2011). Since then the ASEAN region experienced rapid growth in foreign direct investment (Kindra, Strizzi, \& Mansor, 1998), and the total value of deals reached its highest level of \$135 billion in 2007 (Metwalli \& Tang, 2009). Also, authors have looked at growing foreign direct investment by Asian companies (Berrill \& Mannella, 2013; Pananond \& Zeithaml, 1998). For example, Thailand's CP group utilized internationalization strategy for its survival and growth.

For multinational companies, M\&As in ASEAN market are challenging due to lack of supporting elements such as lawyers, accountants and advisers, which are fundamentally important for a successful transaction (Metwalli \& Tang, 2002; Zhan \& Ozawa, 2001); 
companies might have to depend on relational contracting which might be hard to develop in a new country (Indro \& Richards, 2007). Moreover, the cultural difference and high corruption level in ASEAN countries make M\&As less tempting for firms outside the region (Rammal \& Zurbruegg, 2006). Metwalli and Tang (2002) suggest that intra-regional deals will continue to dominate the M\&A market in Southeast Asia in the foreseeable future, especially with the implementation of trade agreements among ASEAN countries and the possibility of a currency union (Huang \& Guo, 2006). Thus, it is interesting to investigate intra-regional M\&As and their performance in ASEAN.

Theoretically, there is a number of reasons why a company could increase its performance through M\&A such as synergies (Larsson \& Finkelstein, 1999), economies of scope and scale (Pangarkar \& Lim, 2003), and greater market monopoly (Ikeda \& Doi, 1983; Lubatkin, 1983; Sharma \& Ho, 2002). In reality, many firms may suffer a decrease in performance from an M\&A activity, as companies face several obstacles which prevent such benefits from being properly executed (Chakrabarti, 1990; Fang, Fridh, \& Schultzberg, 2004; Ivancevich, Schweiger, \& Power, 1987; Nahavandi \& Malekzadeh, 1988; Schweiger \& Denisi, 1991). Obstacles emerge at the level of people and process (Alexandridis, Mavrovitis, \& Travlos, 2012; Shimizu, Hitt, Vaidyanath, \& Pisano, 2004). On one hand, increased formalization of resource allocation and other management decision areas adversely affect performance, and similar challenges emerge at the level of strategic capabilities (Danbolt, 1995). On the other hand, the human aspect of M\&As is equally relevant (Qiu \& Wang, 2011; Shelton, 1988). As the aborted merger between Telia (Swedish) and Telenor (Norwegian) shows, nationalistic sentiments and emotions embedded in employees can cause irreversible damages to cross-border investments (Alexandridis et al., 2012). Indeed, even the managers involved in the M\&A process cannot predict all the issues that are likely to emerge during the integration phase of the deal (Schoenberg, 2006; Slangen, 2006; Very \& 
Schweiger, 2001). A review of works on accounting performance after an M\&A has been provided in the papers by Zollo and Meier (2008), Papadakis and Thanos (2010), and Thanos and Papadakis (2012a, 2012b). Thus, the question of post-M\&A operating performance improvements has been addressed by many researchers over the last three decades (Amel, Barnes, Panetta, \& Salleo, 2004; Healy, Palepu, \& Ruback, 1992; Papadakis \& Thanos, 2010; Spiegel, 2009; Zollo \& Meier, 2008). Companies either experience negative or no gains from M\&As and some studies indicate that acquirers can improve operating performance after M\&As.

The extant literature revolves around M\&As in the USA and UK and most recommendations for outcomes of M\&As are based on the results using samples from these countries as either acquirers or targets. Thus, authors have suggested a need for more geographically diverse samples to overcome the UK and USA bias in the field of M\&A studies (Papadakis \& Thanos, 2010; Thanos \& Papadakis, 2012a). Thanos and Papadakis (2012a, p. 130) specifically suggest a need to look at emerging economies to understand whether the country of origin of acquirers has an impact on M\&A performance. Our study contributes to the limited literature on the long-term performance of M\&As in emerging markets by investigating whether M\&As within ASEAN lead to improvements or deteriorations in operating performance (OP) of involved firms. Moreover, we investigate the relationship between changes in post-M\&A performance and deal characteristics. Also, another important contribution of this paper is that it links the recent global crisis with the performance of M\&As in the ASEAN region.

The rest of the paper is organized as follows. Section 2 presents the summary of relevant literature and develops testable hypotheses. Section 3 describes the data selection and employed methodologies. Section 4 summarizes the main results and examines the determinants of post-M\&A performance. Section 5 concludes. 


\section{Literature review and hypotheses}

Several authors have examined whether M\&As can generate positive gains for merging firms. In order to answer this question, authors have developed several hypotheses to understand the underlying motivations for M\&As (Caves, 1989; Gomes, Angwin, Weber, \& Tarba, 2013; Gugler, Mueller, \& Weichselbaumer, 2012; Gugler, Mueller, Yurtoglu, \& Zulehner, 2003). These hypotheses assume that the managers of the acquirer and target firms anticipate an improvement in profitability, market power, and firm growth. The extant research suggests that there are a number of reasons why an M\&A could improve firm performance through synergies (Larsson \& Finkelstein, 1999), economies of scope and scale (Pangarkar \& Lim, 2003), and market monopoly (Ikeda \& Doi, 1983; Sharma \& Ho, 2002). Yet, firms involved in an M\&A may suffer a decrease in performance due to difficulties at the people and process levels (Fang et al., 2004; Schweiger \& Denisi, 1991). The past and extant literature on post-merger OP improvements indicates positive gains in some studies and negative or no gains in some other studies. Overall, extant evidence offers limited consensus on post-M\&A performance improvements (Amel et al., 2004; Healy et al., 1992; Meglio \& Risberg, 2010; Papadakis \& Thanos, 2010; Schoenberg, 2006). For a comprehensive review of the literature on M\&A performance around the world, see for instance Haleblian, Devers, McNamara, Carpenter, and Davison (2009), Thanos and Papadakis (2012a, 2012b) and Zollo and Meier (2008). A summary of findings from previous empirical studies and their relevant features is displayed in Table 1. Panel A reviews the literature on post-M\&A OP in developed countries, which yields different results depending on the sample and methodology used. Sharma and Ho (2002) assert that the inconsistency in prior studies might be attributable to different measures used to capture changes in OP. 
Table 1: Summary of post-M\&A operating performance studies

\section{Panel A: Developed markets}

\begin{tabular}{|c|c|c|c|c|c|c|c|c|c|}
\hline Market & $\begin{array}{l}\text { Sample } \\
\text { period }\end{array}$ & Author, year & $\begin{array}{l}\text { Sample } \\
\text { size }\end{array}$ & $\begin{array}{l}\text { Performance } \\
\text { measure }\end{array}$ & Deflator & Benchmark & \begin{tabular}{|c|} 
Object of \\
study: \\
Bidder (B) \\
or Target $(\mathrm{T})$
\end{tabular} & $\begin{array}{l}\text { Change } \\
\text { (C) or } \\
\text { Intercept } \\
\text { (I) model }\end{array}$ & $\begin{array}{c}\text { Changes in post-M\&A } \\
\text { profitability }\end{array}$ \\
\hline US & $1952-1963$ & $\begin{array}{l}\text { Lev and } \\
\text { Mandelker, } \\
1972\end{array}$ & 69 & $\begin{array}{l}\text { Net income, Operating } \\
\text { income }\end{array}$ & $\begin{array}{l}\text { (1) BV Assets, } \\
\text { (2) BV Equity, } \\
\text { (3) Sales, } \\
\text { (4) Number of shares }\end{array}$ & Industry, size & B & $\mathrm{C}$ & No significant change \\
\hline US & $1953-1964$ & Hogarty, 1970 & 43 & $\begin{array}{l}\text { (1) EPS } \\
\text { (2) Capital gains }\end{array}$ & Number of shares & Industry & B & Other & Deterioration \\
\hline US & 1967-1987 & Switzer, 1996 & 324 & Pre-tax Cash flow & MV Assets & Industry & $\mathrm{B}+\mathrm{T}$ & $\mathrm{C}+\mathrm{I}$ & Improvement \\
\hline US & 1967-1987 & $\begin{array}{l}\text { Linn and } \\
\text { Switzer, } 2001\end{array}$ & 413 & Pre-tax Cash flow & MV Assets & Industry & $\mathrm{B}+\mathrm{T}$ & $\mathrm{C}$ & Improvement \\
\hline US & 1975-1979 & $\begin{array}{l}\text { Franks et al., } \\
1988\end{array}$ & 42 & $\begin{array}{l}\text { (1) Return on common } \\
\text { equity (ROCE); } \\
\text { (2) Total return to } \\
\text { shareholders (RSH) }\end{array}$ & None & $\begin{array}{l}\text { Industry, size } \\
\text { and pre- } \\
\text { performance }\end{array}$ & B & $\mathrm{C}+\mathrm{I}$ & Deterioration \\
\hline US & 1979-1984 & $\begin{array}{l}\text { Healy et al., } \\
1992\end{array}$ & 50 & Pre-tax Cash flow & MV Assets & Industry & $\mathrm{B}+\mathrm{T}$ & $\mathrm{C}+\mathrm{I}$ & Improvement \\
\hline US & 1981-1988 & $\begin{array}{l}\text { Clark and } \\
\text { Ofek, } 1994\end{array}$ & 38 & Pre-tax Cash flow & Sales & Industry & $\begin{array}{c}\mathrm{B}+ \\
\text { distressed T } \\
\end{array}$ & $\mathrm{C}+\mathrm{I}$ & Deterioration \\
\hline US & 1981-1995 & Ghosh, 2001 & 135 & Pre-tax Cash flow & Adjusted MV Assets & $\begin{array}{l}\text { Industry, size } \\
\text { and pre- } \\
\text { performance }\end{array}$ & $\mathrm{B}+\mathrm{T}$ & $\mathrm{C}+\mathrm{I}$ & No significant change \\
\hline US & $1982-1987$ & $\begin{array}{l}\text { Parrino and } \\
\text { Harris, } 1999\end{array}$ & 197 & Pre-tax Cash flow & MV Assets & Industry & $\mathrm{B}+\mathrm{T}$ & $\mathrm{C}+\mathrm{I}$ & $\begin{array}{l}\text { Improvement only } \\
\text { when target } \\
\text { management is } \\
\text { replaced following the } \\
\text { M\&A }\end{array}$ \\
\hline
\end{tabular}




\begin{tabular}{|c|c|c|c|c|c|c|c|c|c|}
\hline Market & $\begin{array}{l}\text { Sample } \\
\text { period }\end{array}$ & Author, year & $\begin{array}{l}\text { Sample } \\
\text { size }\end{array}$ & $\begin{array}{l}\text { Performance } \\
\text { measure }\end{array}$ & Deflator & Benchmark & \begin{tabular}{|c|} 
Object of \\
study: \\
Bidder (B) \\
or Target $(\mathrm{T})$ \\
\end{tabular} & $\begin{array}{l}\text { Change } \\
\text { (C) or } \\
\text { Intercept } \\
\text { (I) model } \\
\end{array}$ & $\begin{array}{l}\text { Changes in post-M\&A } \\
\text { profitability }\end{array}$ \\
\hline UK & $1948-1977$ & $\begin{array}{l}\text { Dickerson et } \\
\text { al., } 1997\end{array}$ & 1443 & Pre-tax Cash flow & $\begin{array}{l}\text { Average of opening } \\
\text { and closing net assets }\end{array}$ & Industry & B & Other & Deterioration \\
\hline UK & $1985-1993$ & $\begin{array}{l}\text { Powell and } \\
\text { Stark, } 2005\end{array}$ & 191 & $\begin{array}{l}\text { Pre-tax Cash flow } \\
\text { adjusted for changes in } \\
\text { working capital }\end{array}$ & $\begin{array}{l}\text { (1) MV Assets; } \\
\text { (2) Adjusted MV } \\
\text { Assets; } \\
\text { (3) BV Assets; } \\
\text { (4) Sales }\end{array}$ & $\begin{array}{l}\text { Industry, size } \\
\text { and pre- } \\
\text { performance }\end{array}$ & $\mathrm{B}+\mathrm{T}$ & $\mathrm{C}+\mathrm{I}$ & Improvement \\
\hline Japan & $1964-1975$ & $\begin{array}{l}\text { Ikeda and Doi, } \\
1983\end{array}$ & 49 & Pre-tax Cash flow & $\begin{array}{l}\text { (1) BV Equity } \\
\text { (2) BV Assets }\end{array}$ & Industry & $\mathrm{B}+\mathrm{T}$ & $\mathrm{C}$ & Improvement \\
\hline Japan & $1970-1974$ & $\begin{array}{l}\text { Yeh and } \\
\text { Hoshino, } 2002\end{array}$ & 86 & $\begin{array}{l}\text { ROA, ROE, Sales } \\
\text { growth, Employment } \\
\text { growth }\end{array}$ & None & Industry & $\mathrm{B}+\mathrm{T}$ & Other & Deterioration \\
\hline Japan & 1969-1999 & $\begin{array}{l}\text { Kruse et al., } \\
2007\end{array}$ & 69 & Pre-tax Cash flow & $\begin{array}{l}\text { (1) MV Assets } \\
\text { (2) Sales } \\
\end{array}$ & Industry, size & $\mathrm{B}+\mathrm{T}$ & $\mathrm{C}+\mathrm{I}$ & Improvement \\
\hline Greece & $1998-2000$ & $\begin{array}{l}\text { Pazarskis et } \\
\text { al., } 2006\end{array}$ & 50 & $\begin{array}{l}\text { Profitability, Liquidity } \\
\text { and Solvency ratios }\end{array}$ & None & None & B & $\mathrm{C}$ & Deterioration \\
\hline Greece & $1997-2003$ & $\begin{array}{l}\text { Papadakis and } \\
\text { Thanos, } 2010\end{array}$ & 50 & ROA & BV Assets & Industry & $\mathrm{B}+\mathrm{T}$ & $\mathrm{C}$ & No significant change \\
\hline Europe & $1997-2001$ & $\begin{array}{l}\text { Martynova et } \\
\text { al., } 2007\end{array}$ & 155 & $\begin{array}{l}\text { Pre-tax Cash flow } \\
\text { adjusted for changes in } \\
\text { working capital }\end{array}$ & $\begin{array}{l}\text { (1) BV Assets } \\
\text { (2) Sales }\end{array}$ & $\begin{array}{l}\text { Industry, size } \\
\text { and pre- } \\
\text { performance }\end{array}$ & $\mathrm{B}+\mathrm{T}$ & $\mathrm{C}+\mathrm{I}$ & No significant change \\
\hline Australia & 1986-1991 & $\begin{array}{l}\text { Sharma and } \\
\text { Ho, } 2002\end{array}$ & 36 & $\begin{array}{l}\text { Pre-tax Cash flow } \\
\text { adjusted for changes in } \\
\text { working capital }\end{array}$ & $\begin{array}{l}\text { (1) BV Assets, } \\
\text { (2) BV Equity, } \\
\text { (3) Sales, } \\
\text { (4) Number of shares }\end{array}$ & Industry, size & $\mathrm{B}+\mathrm{T}$ & $\mathrm{C}+\mathrm{I}$ & No significant change \\
\hline Canada & 1993-2002 & $\begin{array}{l}\text { Dutta and Jog, } \\
2009\end{array}$ & 1300 & Pre-tax Cash flow & BV Assets & $\begin{array}{l}\text { Industry, size } \\
\text { and pre- } \\
\text { performance }\end{array}$ & B & $\mathrm{C}+\mathrm{I}$ & No significant change \\
\hline
\end{tabular}


Panel B: Emerging markets

\begin{tabular}{|c|c|c|c|c|c|c|c|c|c|}
\hline Market & $\begin{array}{l}\text { Sample } \\
\text { period }\end{array}$ & Author, year & $\begin{array}{l}\text { Sample } \\
\text { size }\end{array}$ & $\begin{array}{l}\text { Performance } \\
\text { measure }\end{array}$ & Deflator & Benchmark & \begin{tabular}{|c|} 
Object of \\
study: \\
Bidder (B) \\
or Target $(\mathrm{T})$
\end{tabular} & $\begin{array}{l}\text { Change } \\
\text { (C) or } \\
\text { Intercept } \\
\text { model (I) }\end{array}$ & $\begin{array}{c}\text { Changes in post-M\&A } \\
\text { profitability }\end{array}$ \\
\hline Malaysia & 1988-1992 & $\begin{array}{l}\text { Rahman and } \\
\text { Limmack, } \\
2004\end{array}$ & 113 & $\begin{array}{l}\text { Pre-tax Cash flow } \\
\text { adjusted for changes in } \\
\text { working capital }\end{array}$ & BV Assets & Industry, size & $\mathrm{B}+\mathrm{T}$ & $\mathrm{C}+\mathrm{I}$ & Improvement \\
\hline India & 2003 & $\begin{array}{l}\text { Kumar and } \\
\text { Bansal, } 2008\end{array}$ & 74 & $\begin{array}{l}\text { Working capital, } \\
\text { operating profit, profit } \\
\text { before tax, ROE, EPS, } \\
\text { debt to equity ratios }\end{array}$ & None & None & B & $\mathrm{C}$ & Improvement \\
\hline India & 1992-1995 & $\begin{array}{l}\text { Pawaskar, } \\
2001\end{array}$ & 36 & Pre-tax Cash flow & Net Assets & Industry, size & B & Other & Deterioration \\
\hline India & 1991-2003 & $\begin{array}{l}\text { Mantravadi } \\
\text { and Reddy, } \\
2008\end{array}$ & 118 & $\begin{array}{l}6 \text { different financial and } \\
\text { operating ratios }\end{array}$ & None & None & B & $\mathrm{C}$ & Deterioration \\
\hline Russia & 1999-2008 & $\begin{array}{l}\text { Bertrand and } \\
\text { Betschinger, } \\
2012\end{array}$ & 609 & Pre-tax Cash flow & BV Assets & $\begin{array}{l}\text { Non- } \\
\text { acquiring } \\
\text { firm }\end{array}$ & B & Other & Deterioration \\
\hline
\end{tabular}


Literature on emerging markets (Panel B) is scarce despite the fast growth of M\&A activity in these countries. In line with developed-market studies, this literature does not yield a homogeneous answer. Two Indian studies (Mantravadi \& Reddy, 2008; Pawaskar, 2001) document a profitability deterioration of bidding firms following a takeover, whereas Kumar and Bansal (2008) show significant improvement in post-M\&A profitability of acquirers. Evidence from Malaysian firms reveals that takeovers are usually associated with a positive change in long-term OP (Rahman \& Limmack, 2004). Since our sample of ASEAN countries include Malaysia, we should expect to find a significant improvement in OP after the M\&A (Rahman \& Limmack, 2004).

H1: The ASEAN firms' M\&A in this region significantly improved its OP.

The extant literature has suggested that deal characteristics like method of payment (Boisot \& Child, 1988; Bradley, Desai, \& Kim, 1988; Haleblian et al., 2009; Jarrell \& Poulsen, 1989; Lindgren, Garcia, \& Saal, 1996; Metwalli \& Tang, 2009), industry relatedness (Boisot \& Child, 1988; Bryson, Crosby, \& Stone, 2006; Healy et al., 1992; Jarrell \& Poulsen, 1989; Metwalli \& Tang, 2009; Sheng, 1996), geographic diversification (Aguiar \& Gopinath, 2007; Chen, 2011; Wang \& Boateng, 2007), acquirer's cash reserves (Jarrell \& Poulsen, 1989; Lindgren et al., 1996; OECD, 2010), target's size (Alexandridis et al., 2012; Boisot \& Child, 1988; Jarrell \& Poulsen, 1989; Lubatkin, 1983; Mantravadi \& Reddy, 2008; Qiu \& Wang, 2011), and percentage of target acquired (Mantravadi \& Reddy, 2008) all impact the performance of M\&As. Also, recent studies have shown that the turbulences in the business environment can have a significant impact on bidder's returns (Beltratti \& Paladino, 2013; Rao-Nicholson \& Salaber, 2014a, 2014b, 2015; Wan \& Yiu, 2009). Thus, it is interesting to look at the impact of the 2007-2008 financial crisis on the OP of M\&As in ASEAN. Though, typically, a financial crisis can have a negative effect on the company's profits, authors have also recognized good M\&A opportunities that present themselves in such an environment 
which can lead to improvement in profitability (Krugman, 2000; Mody \& Negishi, 2000; Wan \& Yiu, 2009). For example, during an economic slump, firms are able to acquire targets at a lower price due to adverse economic conditions. Wan and Yiu (2009) suggest that a crisis provides acquirers with an altered - more abundant - set of opportunities, and companies that spot these opportunities and aggressively pursue them will perform better. From the perspectives of the resource-based view and dynamic capabilities, M\&A during a crisis can be viewed as a way to alter firms' resources and capabilities in order to better adapt to the fast changing environment (Wan \& Yiu, 2009). In the context of the 1997-1999 Asian crisis, the authors find that M\&As are positively related to firm performance during the crisis, and negatively related to performance before and after the crisis. Hence, we formulate several testable hypotheses looking at the combined impact of deal characteristics and crisis period on post-M\&A performance.

\subsection{Method of payment}

Irrespective of the firm's motivations behind cash or stock method for a deal, studies have shown that cash-financed deals are relatively more beneficial to bidding firms (Haleblian et al., 2009). Cash offers can lead to a higher profitability improvement than transactions financed with equity or a mixture of securities (Ghosh, 2001; Linn \& Switzer, 2001). Cash deals give managers incentives to use resources of combined firms more efficiently than stock-swap transactions (Jensen, 1988). In competing bids, a cash offer could help acquirers accomplish the deal faster without any costly delay, making sure they are able to capture the high synergistic value (Berkovitch \& Narayanan, 1990). In the ASEAN context, cash is likely to be used in M\&As as acquiring companies are likely to have superior information about the targets. Yet, during the crisis we might observe valuation mismatch between the acquirer and the target leading to stock-financed M\&As. For Thai firms, authors have observed that firms with the highest debt-equity ratios suffered the most devaluation during the crisis due to their 
capital structure and financial leverage effect (Dekle \& Hoontrakul, 2004). M\&As driven by low value assets might not be motivated by superior information or synergies (Myers \& Majluf, 1984); thus, impacting post-M\&A performance.

H2: Cash-financed M\&As are likely to generate higher post-M\&A OP than stock-financed M\&As. H2a: During the crisis period, stock-financed deals are likely to negatively impact the OP of firms involved in M\&As.

\subsection{Industry relatedness}

M\&As within the same industry can be linked to firms' need for absorbing resources essential for competitive advantage and firm profitability. The occurrence of M\&As between firms in the same industry can considerably change the business environment for surviving firms in that industry (Haleblian et al., 2009). For example, it can increase consolidation and generate excess rents from limited competition in the industry. Also, customers of the target firm, due to reduced commitment to the newly created firm, might examine the market for new suppliers, thus creating growth opportunity for survivor firms. These actions of customers might impact the profitability of the firms after M\&A activity (Berger, Saunders, Scalise, \& Udell, 1998). The findings on industry commonality and takeover effect on OP tend to suggest that M\&As of firms operating in different industries are normally associated with poorer performance compared to industry-related peers (Healy et al., 1992; Jensen, 1986). However, Ghosh (2001) and Kruse, Park, Park, and Suzuki (2007) find opposite results. Furthermore, some studies document no relationship between an M\&A and the combined firms' OP (Fowler \& Schmidt, 1989; Martynova, Oosting, \& Renneboog, 2007; Powell \& Stark, 2005). Within ASEAN countries, there is a high likelihood that acquirers who engage in M\&A activity with industry-related targets could swiftly utilize their established understanding of these markets and leverage their combined capabilities for mutual benefit, and thus, improve post-M\&A performance. On the contrary, during the crisis 
period, diversification could help overcome industry-level contagion. Thus, M\&As within a sector could have a negative impact on post-M\&A OP.

H3: Same-industry M\&As are likely to positively and significantly impact the OP of M\&As. H3a: During the crisis, same-industry M\&As could have a negative impact on OP.

\subsection{Geographic diversification}

The probability of cross-border M\&As depend on several factors including bilateral trade between the two countries and currency exchange rates (Erel, Liao, \& Weisbach, 2012). Authors have argued that geographical diversification can greatly benefit the firms' economic performance (Erel et al., 2012; Indro \& Richards, 2007). Wang and Boateng (2007) conjecture that cross-border M\&As make firms less vulnerable to international dynamics. Beside new resources and customers, foreign targets are also good opportunities for acquiring firms to learn new knowledge and improve their competence (Shimizu et al., 2004). With such advantages, it can be expected that cross-border M\&As will increase the likelihood of synergy realization and improve profitability as observed by Wang and Boateng (2007). However, empirical studies also suggest that when going abroad, firms might face a number of challenges, which could potentially impede the accomplishment of expected synergistic value and even deteriorate the performance of acquiring firms (Kling \& Weitzel, 2011; Moeller \& Schlingemann, 2004). The lack of organizational capabilities has been shown to negatively affect international M\&As of Russian companies (Bertrand \& Betschinger, 2012). Gomes et al. (2013) highlight the importance of cross-cultural sensitivity and communication in cross-border M\&A; and lacking these skills, the firms involved in M\&A activity could experience integration issues. In our study, we consider only intra-regional deals; hence, we argue that the benefits of cross-border deals will overshadow any negative influences emerging from institutional differences between target and bidder countries. Yet, during the crisis, regional contagion might impede value accrual for cross-border M\&As. 
H4: Cross-border deals are likely to increase OP of firms engaged in M\&As as compared to domestic deals.

H4a: During the crisis, companies' performance will be hurt by cross-border M\&As as opposed to domestic deals.

\subsection{Acquirer's cash reserves}

According to the free cash flow theory (Jensen, 1986), a high level of free cash holding could increase the agency costs of firms since the managers tend to get involved in value-destroying investments. The author suggests that M\&As by cash-rich firms are likely to result in operating underperformance relative to those implemented by firms with limited cash holdings. The empirical evidence seems to confirm this conjecture (Harford, 1999; Martynova et al., 2007). This effect is likely to be more acute during the crisis as prudent companies seek to maximize their cash reserves.

H5: Cash-rich firms are likely to engage in M\&As that can negatively impact their OP as compared to cash-poor firms.

H5a: During the crisis, deals executed by cash-rich firms are more likely to cause a decrease in post-M\&A OP.

\subsection{Relative size of target}

Corporate theories suggest that deals of relatively large targets are likely to bring operating and financial advantages, therefore leading to stronger profitability improvement compared to smaller targets (Martynova et al., 2007). Moreover, M\&As that involve relatively large targets enable bidders to quickly take advantage of valuable assets such as strong market position, well-recognized branch, and established distribution network (Alexandridis et al., 2012). However, managers of bidding firms may find it more difficult to assimilate large targets into a combined entity and much of the issues related to large deals has been attributed to managerial hubris which may influence the decision to target larger 
rather than smaller firms for M\&A (Haleblian et al., 2009). Also, the growing size of a company engaged in M\&A could potentially impact the cost of bureaucracy within a company (Bertrand \& Betschinger, 2012; Indro \& Richards, 2007). Most prior empirical research found no significant relation between relative size of target and post-M\&A OP (Chatterjee, 2000; Fowler \& Schmidt, 1989; Powell \& Stark, 2005; Sharma \& Ho, 2002). In the ASEAN region, acquirers invest largely in their own region and engage with known targets; hence enabling them to mitigate any negative impact of size of target in deriving synergies from M\&As. During the crisis, it might be even more beneficial for acquirers to focus on large targets with which they share synergies.

H6: The relative size of the target is likely to have a positive impact on post-M\&A OP.

H6a: During the crisis, the relative size of the target will have an even stronger impact on post-M\&A OP.

2.6. Target share acquired

The percentage of target share acquired in a M\&A directly determines the extent to which bidding firms could exercise their control over the target (Agrawal, Jaffe, \& Gershon, 1992; Jensen \& Ruback, 1983; Travlos, 1987). A deal that leads to a majority shareholding in the target enhances the likelihood of the realization of efficiency combination that could consequently lead to profitability improvement (Mantravadi \& Reddy, 2008). Consistent with previous hypothesis on the size of the target, this effect is likely to be more acute during the crisis when bidders want to derive potential synergies from their M\&As.

H7: The percentage of target share acquired has a positive impact on post-M\&A OP.

H7a: During the crisis, the percentage of target acquired will have an even stronger impact on post-M\&A OP.

2.7. Friendly versus neutral M\&As 
Friendly M\&As, i.e., agreed between acquirer and target managements, are likely to create synergies as compared to other types of deals (Morck, Shleifer, \& Vishny, 1988; Sheng, 1996). Typically M\&As invoke a higher degree of friendly managerial reactions (Huang \& Walkling, 1987). In their study, authors find that $38 \%$ of the target management took neutral position as compared to $49 \%$ of target management who expressed favorable attitude. Authors have also argued that companies from emerging economies like India and China prefer friendly deals over other types of deals (Sun, Peng, Ren, \& Yan, 2012). We argue that this can be equally true for ASEAN countries. This is especially true during the crisis, where friendly deals can help quick assimilation of synergies between the merging companies.

H8: Friendly M\&As will experience performance improvements as opposed to non-friendly deals.

H8a: During the crisis, friendly deals will experience stronger performance improvements.

\section{Data and methodology}

\subsection{Sample selection}

Our study focuses on M\&A activity within ASEAN countries over the period 20012012. We include domestic as well as cross-border transactions, and both target and bidding firms are publicly listed companies. The details of each transaction were extracted from the SDC Platinum of Thomson Financial Securities Data Worldwide Mergers and Acquisitions Database. The data includes transaction value, percentage of shares acquired and owned after the transaction, country and industry of each bidder and target, deal attitude and mode of payment. Financial deals are excluded. We also eliminate transactions from multiple bidders who are involved in more than one deal over the sample period.

In addition, to be included in the sample, bidding and target firms need to have accounting data available for at least one year before and after the takeover. OSIRIS database 
was used to collect accounting data up to three years prior and subsequent to each transaction. Hence we selected deals that were completed between 2004 and 2009 and collected performance data for the years 2001-2012. This procedure is consistent with empirical research in this area as OP induced from corporate takeovers might not materialize for several years (Healy et al., 1992).

\subsection{Sample description}

Table 2 presents descriptive statistics of our final sample of 57 M\&As. Panel A shows a drop in M\&A activity in ASEAN in 2006-2007, although the total transaction value is highest in 2007. M\&A activity is recorded in six ASEAN countries. Panel B shows that Malaysia is the most prolific acquirer country (30\% of deals). For the mode of payment, a third of the takeovers are undertaken using cash only (Panel C). Regarding takeover strategies (Panel D), the sample is divided between focusing (30\%) and diversifying transactions (70\%). Moreover, the majority of transactions in our sample involve relatively large targets (Panel E). Table 2 Panel F shows that domestic deals dominate our ASEAN sample as only $19 \%$ of the deals involve cross-border takeovers.

We define cash reserves as cash equivalents of the bidder divided by its book value of total assets, measured in the year prior to the transaction. Table 2 Panel G shows that the level of cash reserves is fairly distributed among deals and that M\&As completed by cash-rich bidders are not uncommon. Also, there is an equal distribution between majority deals where bidders end up owning more than $50 \%$ of the target and minority deals where less than $50 \%$ of the target is controlled after the M\&A (Panel H). In Panel I, we split the sample into three sub-periods, Pre-crisis includes M\&As completed from 2004 to 2006; Crisis includes transactions from 2007 and 2008; and Post-crisis comprises deals in 2009. Finally, Panel J shows that $75 \%$ of ASEAN deals are friendly, which is consistent with our discussion in section 2.7. 
Table 2: Sample description

Panel A: Completion year

\begin{tabular}{|c|c|c|c|c|c|}
\hline & $\mathrm{N}^{\mathrm{o}}$ of deals & Percent $(\%)$ & \multicolumn{2}{|c|}{ Deal value (\$ million) } & Percent $(\%)$ \\
\hline 2004 & 13 & $23 \%$ & & 429 & $8 \%$ \\
\hline 2005 & 10 & $17 \%$ & & 414 & $8 \%$ \\
\hline 2006 & 5 & $9 \%$ & & 646 & $12 \%$ \\
\hline 2007 & 4 & $7 \%$ & & 2482 & $47 \%$ \\
\hline 2008 & 14 & $25 \%$ & & 1024 & $19 \%$ \\
\hline 2009 & 11 & $19 \%$ & & 333 & $6 \%$ \\
\hline \multicolumn{2}{|r|}{$\mathrm{N}^{\mathrm{o}}$ of deals } & Percent $(\%)$ & $\mathrm{N}^{\mathrm{o}}$ of & deals & Percent $(\%)$ \\
\hline \multicolumn{3}{|c|}{ Panel B: Acquirer country } & \multicolumn{3}{|c|}{ Panel F: Location of deals } \\
\hline Malaysia & 17 & $30 \%$ & Domestic & 46 & $81 \%$ \\
\hline Thailand & 14 & $24 \%$ & Cross-border & 11 & $19 \%$ \\
\hline Singapore & 12 & $21 \%$ & & & \\
\hline Indonesia & 5 & $9 \%$ & \multicolumn{3}{|c|}{ Panel G: Pre-M\&A bidder cash reserves } \\
\hline Vietnam & 5 & $9 \%$ & Cash Q1 & 15 & $26 \%$ \\
\hline \multirow[t]{2}{*}{ Philippines } & 4 & $7 \%$ & Cash Q2 & 17 & $30 \%$ \\
\hline & & & Cash Q3 & 10 & $18 \%$ \\
\hline \multicolumn{3}{|c|}{ Panel C: Mode of payment } & Cash Q4 & 15 & $26 \%$ \\
\hline Cash only & 19 & $33 \%$ & & & \\
\hline Stock only & 6 & $11 \%$ & \multicolumn{3}{|c|}{ Panel H: Target share acquired } \\
\hline Mixed & 5 & $9 \%$ & Minority deals & 27 & $47 \%$ \\
\hline Other/unknown & 27 & $47 \%$ & Majority deals & 30 & $53 \%$ \\
\hline \multicolumn{3}{|c|}{ Panel D: Industry relatedness } & \multicolumn{3}{|l|}{ Panel I: Financial crisis } \\
\hline Consolidation & 17 & $30 \%$ & Pre-crisis & 28 & $49 \%$ \\
\hline \multirow[t]{2}{*}{ Diversification } & 40 & $70 \%$ & Crisis & 18 & $32 \%$ \\
\hline & & & Post-crisis & 11 & $19 \%$ \\
\hline \multicolumn{6}{|c|}{ Panel E: Relative size of target } \\
\hline Small target & 14 & $25 \%$ & Panel J: Deal attitude & & \\
\hline Medium target & 12 & $21 \%$ & Friendly & 43 & $75 \%$ \\
\hline Large target & 31 & $54 \%$ & Neutral & 14 & $25 \%$ \\
\hline
\end{tabular}

Notes: In Panel E, small, medium and large mean that the size of the target (as a proportion of the size of the acquirer) is less than $10 \%$, between $10-20 \%$ and more than $20 \%$, respectively. In Panel G, the four quartiles of pre-M\&A cash reserves are Q1: less than 5\%; Q2: 5-10\%; Q3: 10-15\% and Q4: more than 15\%.

\subsection{Performance measures}

Several post-M\&A accounting-based performance measures have been used in extant literature (Haleblian \& Finkelstein, 1999; Hitt, Harrison, Ireland, \& Best, 1998; Papadakis \& Thanos, 2010; Schoenberg, 2006; Zollo \& Meier, 2008). The rationale for using accounting- 
based measures to evaluate the post-M\&A performance relies on the assumption that most deals are geared towards deriving higher performance for merging firms and this synergy between firms is best observed by looking at long-term accounting measures such as the return on assets (Hitt et al., 1998; Papadakis \& Thanos, 2010; Thanos \& Papadakis, 2012b). Thanos and Papadakis (2012a) suggest that one of the prime motives of M\&As is to exploit the potential synergies between the merging companies and most of these synergies take number of years to realize. Thus, the M\&A performance can be visible in accounting-based measures over a period of time. Also, authors have argued that using multiple measures in a single study gives a more holistic view of the post-M\&A performance (Thanos \& Papadakis, 2012a). Hence, following Bertrand and Betschinger (2012), Papadakis and Thanos (2010) and Boisot and Child (1988), we calculate two measures of post-M\&A performance: the combined return on assets (ROA), measuring the firms' profitability, and the combined sales margin, providing a picture of the firms' effectiveness (Thanos \& Papadakis, 2012a).

We utilize the pretax cash flow as accounting-based performance measure, which is defined as sales, minus cost of goods sold and selling, general, administrative expenses, plus depreciation (Healy et al., 1992; Sudarsanam, 2003). Rather than using raw operating cash flow, the usual approach is to deflate them before and after the deal, in order to make financial ratios comparable between companies and over time. Common bases used to scale operating cash flows are the book value of assets and sales (Clark \& Ofek, 1994). Hence we calculate two cash flow returns of the combined firm (i) for each year (t):

Return on assets $R O A_{i, t}=\frac{C F_{i, t}}{\operatorname{ASSETS}_{i, t}}$

Sales margin $M A R G I N_{i, t}=\frac{C F_{i, t}}{\operatorname{SALES}_{i, t}}$ where $C F$ is the pretax cash flow (EBITDA), ASSETS is the book value of total assets and SALES is the total revenues of the combined firm at the end of the year. For the years before the M\&A, we aggregate accounting figures of target and bidding firms. Following test 
techniques designed by Martynova et al. (2007), pre-M\&A cash flow returns of the combined firm are calculated as the sum of cash flows of both firms scaled by the sum of their total assets or sales at the end of the year.

We do provide a cautionary note that our measures are not without limitations as highlighted by several authors (see Papadakis \& Thanos, 2010 for a review). The main concern about using such accounting measures is the fact that they represent aggregate data for the whole organization (Chenhall \& Langfield-Smith, 2007). Yet, given the context of our study which is similar to the one observed in Papadakis and Thanos (2010), i.e., similar to their study the M\&A market in consideration in this study is a relatively new phenomenon, and thus, the M\&A-related decision-making might be more intuitive than analytical. Also, given the low M\&A intensity of our sampled firms which do not engage in multiple M\&A activities during the period of our study, we believe that there are potentially few confounding events than those observed for UK and USA firms undertaking M\&A activities.

\subsection{Performance benchmarks}

In order to isolate the impact of the $\mathrm{M} \& \mathrm{~A}$ on $\mathrm{OP}$, we need to find a relevant benchmark for each transaction. We use two benchmarks selected on the basis of industry, size and pre-M\&A performance. Our first benchmark controls for industry effects (Healy et al., 1992). Hence, a separate industry portfolio is formed for each acquirer and target firm, which consists of all firms with the same two digits SIC code. To control for industry size, the pool of firms is reconstructed every year. The firm with the median value of operating cash flow return is then selected as the industry median control firm. Our second benchmark also controls for firm size as well as pre-M\&A performance (Dimson \& Marsh, 1986; Ghosh, 2001). To construct industry, size and pre-M\&A performance benchmarks, we first group firms by industry. Then, only firms with size (book value of total assets) that falls within the same quartile as the sample firms are retained. Finally, the firms with the profitability return 
closest to our sample firms are selected as control benchmarks. Our sample firms are carefully removed from the benchmark portfolios.

For each deal, the median values of OP before and after the M\&A (for both sample and control firms) are selected. Then the adjusted OP is calculated by subtracting the median performance of control firms from that of sample firms.

Two performance measures and two control benchmarks give us four adjusted measures of OP: IAROA is the industry-adjusted return on assets, IAMARGIN is the industryadjusted sales margin, ISPAROA is the return on assets adjusted for industry, size and preM\&A performance, and ISPAMARGIN is the sales margin adjusted for industry, size and preM\&A performance.

$I A R O A_{i}=$ median $R O A_{i, t}-$ median $R O A_{\text {ind_peer }, t}$

$\operatorname{IAMARGIN}_{i}=$ median MARGIN $N_{i, t}-$ median MARGIN ind_peer,$t_{1}$

$I S P A R O A_{i}=$ median $R O A_{i, t}-$ median $R O A_{\text {ind_size_perf_peer }, t}$

$\operatorname{ISPAMARGIN}_{i}=$ median MARGIN $N_{i, t}-$ median MARGIN ind_size_perf_peer,$t$

Each performance measure is calculated before and after the transaction, and the Wilcoxon signed rank test will be employed to test whether the change in adjusted profitability of the combined firm is statistically significant following the M\&A.

\subsection{Cross-sectional analysis}

We then perform a multivariate analysis to look at the effect of each variable on our adjusted performance measures. Hence we regress our four measures of post-M\&A OP on various deal characteristics and control variables, based on the following cross-sectional OLS model:

$$
\begin{aligned}
& \text { ADJ_PERF }{ }_{i}(\text { post })=\alpha_{0}+\alpha_{1} \text { ADJ_PERF }_{i}(\text { pre })+\alpha_{2} \text { STOCK }_{i}+\alpha_{3} \text { SAMEIND }_{i}+\alpha_{4} C B_{i} \\
& +\alpha_{5} \text { CASH_RESER VE }_{i}+\alpha_{6} \text { RELATIVESI ZE }_{i}+\alpha_{7} \text { PERC_OWNED }_{i}+\alpha_{8} \text { FRIENDLY }_{i} \\
& +\alpha_{9} \text { CRISIS } \\
& i
\end{aligned}
$$


where $A D J_{-} P E R F_{i}($ post $)$ is the post-M\&A adjusted performance of the combined firm (measured by IAROA ${ }_{i}, \operatorname{IAMARGIN}_{i}, \operatorname{ISPAROA}_{i}$, and ISPAMARGIN $\left.i\right)$ and ADJ_PERF $($ pre) is the pre-M\&A adjusted performance of the combined firm. STOCK $K_{i}$ is a dummy variable equal to one when the deal is all stock financed, zero otherwise (we alternatively use $C A S H_{i}$ as a dummy capturing all cash-financed deals). $S A M E I N D_{i}$ is a dummy variable taking the value one when both bidder and target firms have same first two SIC digits. $C B_{i}$ is a dummy equal to one for cross-border deals, zero otherwise. $C A S H \_R E S E R V E_{i}$ is the level of pre-M\&A cash reserves of the acquirer as defined in section 3.2. RELATIVESIZE $E_{i}$ measures the size of the target relative to the size of the bidder. PERC_OWNED $i$ represents the percentage of target share owned after the transaction. FRIENDLY $Y_{i}$ is a dummy variable which equals one for friendly deals, zero otherwise. Finally, $\operatorname{CRISIS}_{i}$ is a dummy capturing the effect of the global crisis, i.e., it is equal to one for deals completed in 2007 and 2008.

We also investigate the combined impact of the crisis and deal characteristics by interacting the dummy CRISIS with all other variables in the model.

\section{Results and Discussion}

\subsection{Change in operating performance}

Table 3 shows the post-M\&A changes in OP for our different performance measures. Specifically, findings indicate that M\&As in ASEAN countries have a detrimental impact on both raw performance and adjusted performance of merging firms. This decrease in OP is significant for IAROA (equal to $-2.25 \%$ ), which is consistent with previous empirical studies (Clark \& Ofek, 1994; Dickerson, Gibson, \& Tsakalotos, 1997). However, the fact that other measures do not yield any significant difference between pre- and post-M\&A performance supports the conjecture of Sharma and Ho (2002). 
Table 3: Changes in operating performance

\begin{tabular}{|c|c|c|c|}
\hline & Pre-M\&A & Post-M\&A & Difference \\
\hline \multicolumn{4}{|l|}{ Raw performance } \\
\hline ROA & 10.58 & 9.53 & -0.55 \\
\hline MARGIN & 13.86 & 14.11 & -0.07 \\
\hline \multicolumn{4}{|l|}{ Industry-adjusted performance } \\
\hline IAROA & $1.60^{\text {(a) }}$ & -0.33 & $-2.25 * *$ \\
\hline & $(38)$ & $(25)$ & $(17)$ \\
\hline IAMARGIN & $1.75^{\text {(b) }}$ & $0.96^{(\mathrm{c})}$ & -0.69 \\
\hline & (31) & (31) & (26) \\
\hline \multicolumn{4}{|c|}{ Performance adjusted for industry, size and pre-M\&A performance } \\
\hline ISPAROA & -0.26 & -0.53 & -1.04 \\
\hline & $(28)$ & (27) & (27) \\
\hline ISPAMARGIN & -0.78 & -0.95 & 2.24 \\
\hline & (26) & (25) & (32) \\
\hline
\end{tabular}

Notes: Percentage of positive values is reported in brackets.

(a) $f^{\text {(b) }} f^{\text {(c) }}$ significance at $1 \%, 5 \%, 10 \%$ using Wilcoxon ranked test which shows that combined firm's performance is significantly different from benchmark's performance.

$* * * / * * *$ significance at $1 \%, 5 \%, 10 \%$ using Wilcoxon ranked test which shows that the median post-M\&A performance is significant different from the median pre-M\&A performance.

Another important finding presented in Table 3 is that merging firms significantly outperform their respective industry benchmark before the M\&A $(+1.6 \%$ for IAROA and $+1.75 \%$ for IAMARGIN). This implies that, on average, firms in ASEAN countries are likely to engage in M\&As during a period when they experience a superior level of OP relative to the industry. For the years subsequent to the transaction, merging firms continue to retain a higher level of performance (measured by IAMARGIN) but to a smaller extent. This finding is in line with empirical evidence from other studies (Heron \& Lie, 2002; Kruse et al., 2007; Martynova et al., 2007; Rahman \& Limmack, 2004) and reinforces the suggestions of Ghosh (2001) that empirical studies should take into account the pre-event performance of merging firms when selecting control benchmarks. 
Table 4: Deal characteristics and changes in operating performance

\begin{tabular}{|c|c|c|c|c|}
\hline & IAROA & IAMARGIN & ISPAROA & ISPAMARGIN \\
\hline Cash only & $-3.2^{* *}$ & -2.9 & -2.9 & -3 \\
\hline Mixed & -1.7 & -1.2 & 4.2 & $3.3^{* *}$ \\
\hline Stock only & -3.5 & 0.8 & -1.8 & 2.6 \\
\hline Diff (Cash - Stock) & 0.3 & -3.7 & -1.1 & -5.6 \\
\hline Consolidation & -1.9 & -1.4 & 1.7 & 2.6 \\
\hline Diversification & $-2.5^{* *}$ & 1.1 & -1.4 & 2.1 \\
\hline Diff (Cons - Div) & 0.6 & -2.5 & 3.1 & 0.5 \\
\hline Large target & $-2.2^{* *}$ & -1.4 & -0.5 & 1.9 \\
\hline Medium target & -1.4 & $3.2 * * *$ & 2.3 & 3.6 \\
\hline Small target & -2.9 & -2 & -2.8 & 2.1 \\
\hline Diff (Large - Small) & 0.7 & 0.6 & 2.3 & -0.2 \\
\hline Cross-border & -1.9 & -1.7 & -1 & 2.8 \\
\hline Domestic & $-2.3^{* *}$ & -0.4 & -1.2 & 2.1 \\
\hline Diff (CB - Domestic) & 0.4 & -1.3 & 0.2 & 0.7 \\
\hline Cash Q1 & $-3.0^{* *}$ & -2 & -2.5 & -3.2 \\
\hline Cash Q2 & -1.1 & -1.7 & $3.0^{* *}$ & 1.9 \\
\hline Cash Q3 & -2.2 & -0.4 & -1.9 & 2.7 \\
\hline Cash Q4 & -1.1 & 3.3 & -1.6 & 7.8 \\
\hline Diff (Q4 - Q1) & 1.9 & 5.3 & 0.9 & 11 \\
\hline Minority deals & $-1.9^{* *}$ & 2.9 & -2.5 & 2.8 \\
\hline Majority deals & -2.3 & -1.2 & 0.4 & 1.9 \\
\hline Diff (Minority - Majority) & 0.4 & $4.1^{*}$ & -2.9 & 0.9 \\
\hline Friendly deals & $-2.3 * *$ & -0.4 & -1.1 & $2.7 *$ \\
\hline Neutral deals & -2 & -2.1 & 0 & -1.6 \\
\hline Diff (Friendly - Neutral) & -0.2 & 1.7 & -1.1 & $4.4^{*}$ \\
\hline Pre-crisis & $-2.8 * *$ & -2.2 & -1.5 & -0.5 \\
\hline Crisis & -0.6 & $3.2 * *$ & 5.4 & $6.0 * *$ \\
\hline Post-crisis & -3.2 & 1.1 & 4.6 & 0.6 \\
\hline Diff (Post - Pre) & -0.4 & 3.3 & $6.1 * *$ & 1.1 \\
\hline
\end{tabular}

Notes: Small, medium and large target mean that the size of the target (as a proportion of the size of the acquirer) is less than $10 \%$, between $10-20 \%$ and more than $20 \%$, respectively. The four quartiles of pre-M\&A cash reserves are Q1: less than 5\%; Q2: 5-10\%; Q3: 10-15\% and Q4: more than 15\%.

$* * * / * * * *$ Significant at $1 \%, 5 \%, 10 \%$ levels. Wilcoxon ranked test was used to test for the statistical significance of the change in operating performance (median post-M\&A performance minus median pre-M\&A performance). Mann-Whitney test was used to test for the statistical difference in performance changes between sub-groups of deals. 


\subsection{Deal characteristics}

This section focuses on discovering the sources of OP of merging firms. Changes in OP for different sub-groups of deals are presented in Table 4.

First, the adjusted profitability does not differ significantly between cash-financed and stock-financed M\&As, which is consistent with prior empirical studies (Healy et al., 1992; Heron \& Lie, 2002; Martynova et al., 2007; Powell \& Stark, 2005; Sharma \& Ho, 2002). Also, the combined offer of cash and stock is associated with significantly positive changes in performance (ISPAMARGIN). Second, focusing M\&As are not able to generate more synergistic benefits for merging firms than diversifying ones, consistent with previous studies (Fowler \& Schmidt, 1989; Martynova et al., 2007; Powell \& Stark, 2005). Third, the change in OP is statistically the same between small and large targets. Fourth, geographic scope of business expansion does not help explain the sequent changes in post-M\&A performance in ASEAN.

Fifth, the change in OP does not significantly differ for cash-rich and cash-poor companies, which is in contrast with other studies (Harford, 1999; Martynova et al., 2007). Sixth, results for the percentage acquired do not provide any evidence that majority deals significantly outperform minority deals. We find the opposite result for IAMARGIN. Seventh, friendly M\&As provide significantly better OP improvements when ISPAMARGIN is used.

Finally, we test whether economic downturn would have any impact on OP by comparing pre-crisis and post-crisis deals. Results for ISPAROA show that post-crisis M\&As benefited from a higher increase in performance than pre-crisis transactions. Moreover, takeovers during the crisis were associated with a significant increase in sales margin (IAMARGIN and ISPAMARGIN). 
Table 5: Correlation table

\begin{tabular}{|c|c|c|c|c|c|c|c|c|c|c|c|c|c|c|c|c|}
\hline & 1 & 2 & 3 & 4 & 5 & 6 & 7 & 8 & 9 & 10 & 11 & 12 & 13 & 14 & 15 & 16 \\
\hline 1 IAROA(post) & 1.00 & & & & & & & & & & & & & & & \\
\hline 2 IAROA(pre) & $0.67^{3}$ & 1.00 & & & & & & & & & & & & & & \\
\hline 3 IAMARGIN(post) & $0.58^{3}$ & $0.39^{3}$ & 1.00 & & & & & & & & & & & & & \\
\hline 4 IAMARGIN(pre) & $0.45^{3}$ & $0.61^{3}$ & $0.56^{3}$ & 1.00 & & & & & & & & & & & & \\
\hline 5 ISPAROA(post) & $0.70^{3}$ & $0.39^{3}$ & $0.41^{3}$ & 0.14 & 1.00 & & & & & & & & & & & \\
\hline 6 ISPAROA(pre) & $0.25^{1}$ & $0.67^{3}$ & 0.16 & $0.38^{3}$ & $0.34^{2}$ & 1.00 & & & & & & & & & & \\
\hline 7 ISPAMARGIN(post) & $0.28^{2}$ & 0.10 & $0.72^{3}$ & 0.13 & $0.51^{3}$ & 0.17 & 1.00 & & & & & & & & & \\
\hline 8 ISPAMARGIN(pre) & 0.06 & 0.12 & 0.14 & $0.42^{3}$ & 0.08 & $0.26^{2}$ & 0.19 & 1.00 & & & & & & & & \\
\hline $9 \mathrm{CASH}$ & -0.05 & 0.04 & -0.08 & 0.09 & 0.05 & $0.28^{2}$ & -0.03 & 0.21 & 1.00 & & & & & & & \\
\hline 10 STOCK & 0.06 & 0.23 & -0.02 & 0.18 & 0.00 & $0.12^{2}$ & -0.20 & 0.02 & -0.24 & 1.00 & & & & & & \\
\hline 11 SAMEIND & 0.01 & -0.12 & -0.07 & 0.03 & -0.10 & -0.14 & 0.00 & 0.01 & 0.03 & -0.10 & 1.00 & & & & & \\
\hline $12 \mathrm{CB}$ & 0.06 & 0.04 & 0.08 & 0.04 & 0.00 & $-0.23^{1}$ & -0.09 & -0.08 & -0.06 & 0.12 & -0.03 & 1.00 & & & & \\
\hline 13 CASH_RESERVE & 0.16 & 0.17 & 0.21 & 0.10 & $0.24^{1}$ & $0.22^{1}$ & $0.25^{1}$ & 0.01 & 0.18 & -0.14 & -0.16 & -0.19 & 1.00 & & & \\
\hline 14 RELATIVESIZE & 0.01 & -0.07 & 0.18 & -0.07 & 0.16 & 0.03 & 0.20 & -0.04 & -0.06 & -0.11 & 0.03 & 0.18 & 0.12 & 1.00 & & \\
\hline 15 PERC_OWNED & 0.04 & -0.02 & -0.10 & -0.05 & 0.04 & -0.03 & -0.08 & -0.06 & 0.00 & $0.48^{3}$ & $0.29^{2}$ & 0.13 & -0.15 & -0.15 & 1.00 & \\
\hline 16 FRIENDLY & -0.01 & 0.03 & -0.01 & -0.13 & 0.08 & 0.07 & -0.01 & $-0.36^{3}$ & -0.12 & 0.20 & 0.02 & 0.07 & 0.11 & 0.09 & 0.25 & 1.00 \\
\hline 17 CRISIS & 0.07 & 0.00 & 0.20 & 0.05 & 0.13 & -0.17 & 0.13 & -0.13 & $-0.24^{1}$ & 0.01 & -0.20 & 0.05 & 0.11 & 0.15 & -0.17 & 0.04 \\
\hline
\end{tabular}

Significance level of each correlation coefficient: ${ }^{3} \mathrm{p}<0.01,{ }^{2} \mathrm{p}<0.05,{ }^{1} \mathrm{p}<0.1$ 
Table 6: Cross-sectional analysis of post-M\&A operating performance

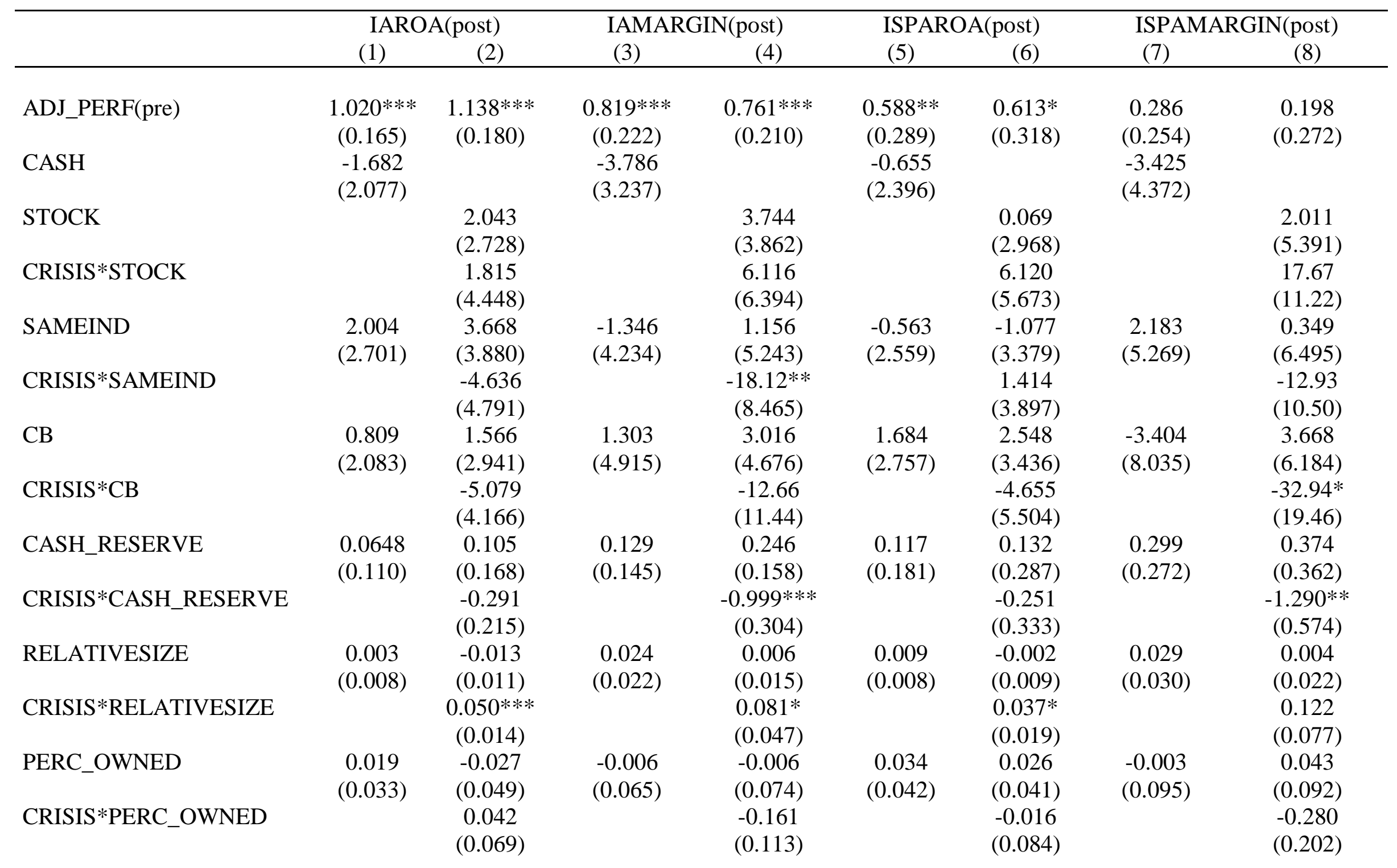




\begin{tabular}{|c|c|c|c|c|c|c|c|c|}
\hline FRIENDLY & $\begin{array}{l}-1.651 \\
(2.669)\end{array}$ & $\begin{array}{l}-0.832 \\
(2.864)\end{array}$ & $\begin{array}{c}0.682 \\
(3.653)\end{array}$ & $\begin{array}{l}-6.357 \\
(4.449)\end{array}$ & $\begin{array}{l}-0.523 \\
(2.455)\end{array}$ & $\begin{array}{l}-0.501 \\
(2.558)\end{array}$ & $\begin{array}{c}1.262 \\
(4.444)\end{array}$ & $\begin{array}{l}-7.645 \\
(6.065)\end{array}$ \\
\hline CRISIS*FRIENDLY & & $\begin{array}{c}-0.548 \\
(4.477)\end{array}$ & & $\begin{array}{c}22.38 * * * \\
(6.244)\end{array}$ & & $\begin{array}{c}0.104 \\
(4.859)\end{array}$ & & $\begin{array}{l}20.46 * * \\
(9.297)\end{array}$ \\
\hline CRISIS & $\begin{array}{c}1.246 \\
(1.889)\end{array}$ & & $\begin{array}{c}3.035 \\
(4.344)\end{array}$ & & $\begin{array}{c}3.298 \\
(2.632)\end{array}$ & & $\begin{array}{c}4.313 \\
(6.709)\end{array}$ & \\
\hline Constant & $\begin{array}{l}-2.544 \\
(3.556)\end{array}$ & $\begin{array}{l}-3.129 \\
(2.876)\end{array}$ & $\begin{array}{l}-1.094 \\
(5.170)\end{array}$ & $\begin{array}{l}-0.509 \\
(4.130)\end{array}$ & $\begin{array}{l}-4.130 \\
(3.252)\end{array}$ & $\begin{array}{c}-3.473 \\
(4.011)\end{array}$ & $\begin{array}{l}-4.806 \\
(6.561)\end{array}$ & $\begin{array}{l}-1.963 \\
(7.744)\end{array}$ \\
\hline Observations & 57 & 57 & 56 & 56 & 57 & 57 & 56 & 56 \\
\hline R-squared & 0.480 & 0.560 & 0.412 & 0.608 & 0.203 & 0.260 & 0.150 & 0.343 \\
\hline Adjusted R-squared & 0.381 & 0.399 & 0.297 & 0.461 & 0.051 & -0.011 & -0.016 & 0.097 \\
\hline
\end{tabular}

Notes: Robust standard errors in parentheses

$* * * \mathrm{p}<0.01, * * \mathrm{p}<0.05, * \mathrm{p}<0.1$ 


\subsection{Cross-sectional analysis}

In this section, we explore the combined effect of the determinants of the post-M\&A performance in a multivariate framework. Table 5 presents the correlation coefficients (and statistical significance) among all our variables. We do not observe any significant correlations that could bias our analysis.

Table 6 presents the coefficient estimates from the cross-sectional analysis for each performance measure and for different combinations of the independent variables. The dependent variable is the post-M\&A adjusted OP (IAROA, IAMARGIN, ISPAROA, and ISPAMARGIN) and ADJ_PERF(pre) is the corresponding pre-M\&A performance. In this analysis, robust standard errors (White estimator) were used. Models with odd numbers report coefficient estimates without interaction between variables, and even-numbered models report the results including crisis interaction terms. Across specifications, pre-M\&A OP has a strong and positive impact on post-M\&A performance, which is expected. The fact that the statistical significance of $A D J \_P E R F($ pre) decreases for ISPAROA and disappears for ISPAMARGIN is also expected, as these measures of performance are already adjusted for pre-M\&A performance. Over the entire sample period, we observe that none of the deal characteristics have a significant impact on post-M\&A OP. Nevertheless, it is interesting to note that this changes during the crisis period. Indeed, several coefficients become statistically significant when deal characteristics are interacted with the CRISIS dummy.

On one side, SAMEIND, $C B$ and $C A S H \_R E S E R V E$ have a negative impact on postM\&A performance (measured by sales margin) for deals completed during the crisis. These results are consistent with our hypotheses $\mathrm{H} 3 \mathrm{a}, \mathrm{H} 4 \mathrm{a}$ and $\mathrm{H} 5 \mathrm{a}$, as well as previous empirical evidence (Harford, 1999; Kruse et al., 2007; Martynova et al., 2007; Moeller \& Schlingemann, 2004). Hence, during bad economic times, ASEAN firms should concentrate 
on diversifying M\&As within their own borders. Moreover, during crisis, a large amount of cash holding is particularly detrimental for acquirers.

On the other side, RELATIVESIZE and FRIENDLY both impact positively the postM\&A performance of transactions completed in 2007-2008. These findings support our hypotheses H6a and H8a, as well as existing studies (Martynova et al., 2007; Morck et al., 1988; Shelton, 1988; Sun et al., 2012). ASEAN firms are able to generate extra performance from friendly M\&As with large targets only during the crisis period. Finally, we do not find support for $\mathrm{H} 2 \mathrm{a}$ (stock-financed deals) and H7a (percentage of target owned).

\subsection{Robustness checks}

We undertook a series of tests to verify the robustness of our results. First, we used $C A S H$ as an explanatory variable instead of STOCK. The interaction between $C A S H$ and CRISIS doesn't offer any statistical significance. Similarly, we removed from the regression the explanatory variables that were not significant, namely STOCK $(C A S H)$ and PERC_ OWNED. Our results remain similar. Second, we removed the control variable ADJ_PERF(pre) from the regression to account for the fact that ISPAROA and ISPAMARGIN are already adjusted for pre-M\&A performance. Results are similar to those presented in the paper. Finally, instead of regressing ADJ_PERF(post) on ADJ_PERF(pre) and other variables, we directly used the difference in adjusted performance as the dependent variable. Following other studies (Ramaswamy, 1997; Zollo \& Singh, 2004), we calculated for each deal the difference between post-M\&A and pre-M\&A performance and tried to explain the change using our explanatory variables. Again our conclusions remain unchanged.

\section{Concluding remarks}

This paper contributes to the literature on mergers and acquisitions (M\&As) in emerging markets by investigating post-M\&A performance of ASEAN companies over 20012012. Using various measures of adjusted operating performance (OP) and conducting both 
univariate and multivariate analyses, we find, on average, a deterioration of post-M\&A performance of the combined firms as measured by the return on assets. This result is consistent with previous studies where authors find a negative impact of M\&A activity (Alexandridis et al., 2012; Bertrand \& Betschinger, 2012; Brouthers \& Brouthers, 2000; Danbolt, 1995; Indro \& Richards, 2007; Kindra et al., 1998; Kumar \& Bansal, 2008; Pawaskar, 2001; Qiu \& Wang, 2011; Shelton, 1988; Shimizu et al., 2004; Zhan \& Ozawa, 2001). When taking into consideration the impact of the 2007-2008 financial crisis, from the multivariate analysis, we find that the decrease in performance is particularly significant for M\&As that are engaged in cross-border deals and have high cash reserves and observe negative effect of diversification for deals during this period. These findings are consistent with prior works (Jarrell \& Poulsen, 1989; OECD, 2010; Sheng, 1996). We find positive impact of relative size and friendly deals on post-M\&A OP (Alexandridis et al., 2012; Jarrell \& Poulsen, 1989; Morck et al., 1988; Sun et al., 2012). This result is particularly interesting as it shows how the crisis can affect the long-term performance of M\&As in ASEAN countries. Moreover, our results help explain that inconsistent findings across previous empirical studies may be the result of differences in adjustment bases, performance measures or model specifications. For instance, our results significantly differ when using return on assets and sales margin.

Our findings have several managerial implications. In times of crisis, managers can be expected to do well if they focus on their domestic markets and access domestic firms for M\&As. The argument in favor of this domestic consolidation would be the growth in market power which might help firms weather the crisis in their business environment. Also, during the crisis, managers must prudently focus on strengthening their capabilities in their core sector and avoiding unnecessary diversification through M\&As. Finally, managers might want to focus on deals that are friendly and where the target's board and employees are 
amicable to M\&A. Indeed friendly deals help in the easier integration of the two companies and managers can work proactively to derive sooner synergistic gains from their M\&A activity.

It is acknowledged that the current study has a number of limitations; therefore the results may not provide a comprehensive picture in understanding the long-term $\mathrm{OP}$ of M\&As. In particular, companies selected in this study were restricted to publicly listed firms. Thus, future studies should try to include private acquirers as well as targets. This will help identify the differences between the M\&A dynamics of private and public acquirers and targets. Moreover, this study used extant methodology of analyzing changes in OP three years following the M\&A. Yet, it is not clear whether merging companies can derive all the synergistic value within this timeframe, and studies over a longer period will provide an insight into M\&A performance in ASEAN. Hence, we suggest that future research should look to undertake an analysis over a longer time horizon, e.g. up to 7 years. In this study we present a holistic view of the M\&A activity within ASEAN region, and do not examine the global M\&A activities of firms from this region. For instance do ASEAN firms engage more actively in M\&As within this region as compared to the rest of the world? Also, we do not investigate the micro-foundations of these M\&A activities Are there any micro-founded reasons for this? For example are managers in this region more likely to link through ethnic communities and diaspora (e.g. Chinese ethnic communities) and engage in regional M\&A activities than managers in other regions? 


\section{Reference List}

Agrawal, A., Jaffe, J. F., \& Gershon, N. M. (1992). The Post-Merger Performance of Acquiring Firms: A Re-Examination of an Anomaly. The Journal of Finance, 47(4), 1605-1621.

Aguiar, M., \& Gopinath, G. (2007). Emerging Market Business Cycles: The Cycle Is the Trend. [Article]. Journal of political economy, 115(1), 69-102.

Alexandridis, G., Mavrovitis, C. F., \& Travlos, N. G. (2012). How have M\&As changed? Evidence from the sixth merger wave. The European Journal of Finance, 18(8), 663688.

Amel, D., Barnes, C., Panetta, F., \& Salleo, C. (2004). Consolidation and efficiency in the financial sector: A review of the international evidence. Journal of Banking \& Finance, 28(10), 2493-2519.

Anwar, S., \& Nguyen, L. P. (2011). Foreign direct investment and trade: The case of Vietnam. Research in International Business and Finance, 25(1), 39-52.

Beltratti, A., \& Paladino, G. (2013). Is M\&A different during a crisis? Evidence from the European banking sector. Journal of Banking \& Finance, 37(12), 5394 -5405.

Berger, A. N., Saunders, A., Scalise, J. M., \& Udell, G. F. (1998). The effects of bank mergers and acquisitions on small business lending. Journal of financial economics, 50(2), 187-229.

Berkovitch, E., \& Narayanan, M. (1990). Competition and the medium of exchange in takeovers. Review of Financial Studies, 3(2), 153-174.

Berrill, J., \& Mannella, G. (2013). Are firms from developed markets more international than firms from emerging markets? Research in International Business and Finance, 27(1), 147-161.

Bertrand, O., \& Betschinger, M.-A. (2012). Performance of domestic and cross-border acquisitions: Empirical evidence from Russian acquirers. Journal of comparative economics, 40(3), 413-437.

Boisot, M., \& Child, J. (1988). The iron law of fiefs: Bureaucratic failure and the problem of governance in the Chinese economic reforms. Administrative Science Quarterly, 507527.

Bradley, M., Desai, A., \& Kim, E. H. (1988). Synergistic gains from corporate acquisitions and their division between the stockholders of target and acquiring firms. Journal of financial economics, 21(1), 3-40.

Brouthers, K. D., \& Brouthers, L. E. (2000). Acquisition or greenfield start-up? Institutional, cultural and transaction cost influences. Strategic Management Journal, 21(1), 89-97.

Bryson, J. M., Crosby, B. C., \& Stone, M. M. (2006). The Design and Implementation of Cross-Sector Collaborations: Propositions from the Literature. Public Administration Review, 66(s1), 44-55.

Caves, R. E. (1989). Mergers, takeovers, and economic efficiency: foresight vs. hindsight. International Journal of Industrial Organization, 7(1), 151-174.

Chakrabarti, A. K. (1990). Organizational factors in post-acquisition performance. Engineering Management, IEEE Transactions on, 37(4), 259-268.

Chatterjee, R. A. (2000). The financial performance of companies acquiring very large takeover targets. Applied financial economics, 10(2), 185-191.

Chen, W. (2011). The effect of investor origin on firm performance: Domestic and foreign direct investment in the United States. Journal of international economics, 83(2), 219228.

Chenhall, R. H., \& Langfield-Smith, K. (2007). Multiple perspectives of performance measures. European Management Journal, 25(4), 266-282. 
Clark, K., \& Ofek, E. (1994). Mergers as a means of restructuring distressed firms: an empirical investigation. Journal of Financial and Quantitative Analysis, 29(4).

Danbolt, J. (1995). An analysis of gains and losses to shareholders of foreign bidding companies engaged in cross-border acquisitions into the United Kingdom, 1986-1991. The European Journal of Finance, 1(3), 279-309.

Dekle, R., \& Hoontrakul, P. (2004). An empirical and institutional examination of post-crisis capital flows-Thailand case. Research in International Business and Finance, 18(3), 291-303.

Dickerson, A. P., Gibson, H. D., \& Tsakalotos, E. (1997). The impact of acquisitions on company performance: Evidence from a large panel of UK firms. Oxford Economic Papers, 49(3), 344-361.

Dimson, E., \& Marsh, P. (1986). Event study methodologies and the size effect: The case of UK press recommendations. Journal of financial economics, 17(1), 113-142.

Dutta, S., \& Jog, V. (2009). The long-term performance of acquiring firms: A re-examination of an anomaly. Journal of Banking \& Finance, 33(8), 1400-1412.

Economist. (2009). An Astonishing Rebound. Retrieved from http://www.economist.com/ node/14214001

Erel, I., Liao, R. C., \& Weisbach, M. S. (2012). Determinants of Cross-Border Mergers and Acquisitions. The Journal of Finance, 67(3), 1045-1082.

Fang, T., Fridh, C., \& Schultzberg, S. (2004). Why did the Telia-Telenor merger fail? International Business Review, 13(5), 573-594.

Fowler, K. L., \& Schmidt, D. R. (1989). Determinants of tender offer post-acquisition financial performance. Strategic Management Journal, 10(4), 339-350.

Ghosh, A. (2001). Does operating performance really improve following corporate acquisitions? Journal of Corporate Finance, 7(2), 151-178.

Gomes, E., Angwin, D. N., Weber, Y., \& Tarba, S. Y. (2013). Critical Success Factors through the Mergers and Acquisitions Process: Revealing Pre- and Post-M\&A Connections for Improved Performance. [Article]. Thunderbird international business review, 55(1), 13-35.

Gugler, K., Mueller, D. C., \& Weichselbaumer, M. (2012). The determinants of merger waves: An international perspective. International Journal of Industrial Organization, $30(1), 1-15$.

Gugler, K., Mueller, D. C., Yurtoglu, B. B., \& Zulehner, C. (2003). The effects of mergers: an international comparison. International Journal of Industrial Organization, 21(5), 625-653.

Haleblian, J., Devers, C. E., McNamara, G., Carpenter, M. A., \& Davison, R. B. (2009). Taking stock of what we know about mergers and acquisitions: A review and research agenda. Journal of management.

Haleblian, J., \& Finkelstein, S. (1999). The influence of organizational acquisition experience on acquisition performance: A behavioral learning perspective. Administrative Science Quarterly, 44(1), 29-56.

Harford, J. (1999). Corporate cash reserves and acquisitions. The Journal of Finance, 54(6), 1969-1997.

Healy, P., Palepu, K., \& Ruback, R. (1992). Does corporate performance improve after mergers? Journal of Financial Economics, 31(2), 135-175.

Heron, R., \& Lie, E. (2002). Operating performance and the method of payment in takeovers. Journal of Financial and Quantitative Analysis, 37(01), 137-155.

Hitt, M., Harrison, J., Ireland, R. D., \& Best, A. (1998). Attributes of successful and unsuccessful acquisitions of US firms. British Journal of Management, 9(2), 91-114. 
Huang, Y.-S., \& Walkling, R. A. (1987). Target abnormal returns associated with acquisition announcements: Payment, acquisition form, and managerial resistance. Journal of financial economics, 19(2), 329-349.

Huang, Y., \& Guo, F. (2006). Is currency union a feasible option in East Asia?: A multivariate structural VAR approach. Research in International Business and Finance, 20(1), 77-94.

Ikeda, K., \& Doi, N. (1983). The performances of merging firms in Japanese manufacturing industry: 1964-75. The Journal of Industrial Economics, 31(3), 257-266.

Indro, D. C., \& Richards, M. (2007). The determinants of foreign partner's equity ownership in Southeast Asian joint ventures. International Business Review, 16(2), 177-206.

Ivancevich, J. M., Schweiger, D. M., \& Power, F. R. (1987). Strategies for managing human resources during mergers and acquisitions. Human Resource Planning, 10(1), 19-35.

Jarrell, G. A., \& Poulsen, A. B. (1989). The returns to acquiring firms in tender offers: Evidence from three decades. Financial Management, 12-19.

Jensen, M. C. (1986). Agency costs of free cash flow, corporate finance, and takeovers. The American Economic Review, 76(2), 323-329.

Jensen, M. C. (1988). Takeovers: Their causes and consequences. The Journal of Economic Perspectives, 2(1), 21-48.

Jensen, M. C., \& Ruback, R. S. (1983). The market for corporate control: The scientific evidence. Journal of financial economics, 11(1), 5-50.

Kindra, G. S., Strizzi, N., \& Mansor, N. (1998). The role of marketing in FDI generation: evidence from ASEAN countries. International Business Review, 7(4), 399-421.

Kling, G., \& Weitzel, U. (2011). The internationalization of Chinese companies: firm characteristics, industry effects and corporate governance. Research in International Business and Finance, 25(3), 357-372.

Krugman, P. (2000). Fire-sale FDI Capital flows and the emerging economies: theory, evidence, and controversies (pp. 43-60): University of Chicago Press.

Kruse, T. A., Park, H. Y., Park, K., \& Suzuki, K. (2007). Long-term performance following mergers of Japanese companies: The effect of diversification and affiliation. PacificBasin Finance Journal, 15(2), 154-172.

Kumar, S., \& Bansal, L. K. (2008). The impact of mergers and acquisitions on corporate performance in India. Management Decision, 46(10), 1531-1543.

Larsson, R., \& Finkelstein, S. (1999). Integrating strategic, organizational, and human resource perspectives on mergers and acquisitions: A case survey of synergy realization. Organization science, 10(1), 1-26.

Lev, B., \& Mandelker, G. (1972). The microeconomic consequences of corporate mergers. Journal of Business, 85-104.

Lindgren, C.-J., Garcia, G. G., \& Saal, M. I. (1996). Bank soundness and macroeconomic policy: International Monetary Fund.

Linn, S. C., \& Switzer, J. A. (2001). Are cash acquisitions associated with better postcombination operating performance than stock acquisitions? Journal of Banking \& Finance, 25(6), 1113-1138.

Lubatkin, M. (1983). Mergers and the Performance of the Acquiring Firm. Academy of Management Review, 8(2), 218-225.

Mantravadi, P., \& Reddy, A. (2008). Type of Merger and Impact on Operating Performance: The Indian Experience. Economic and Political Weekly, 43(39), 66-74.

Martynova, M., Oosting, S., \& Renneboog, L. (2007). The long-term operating performance of European mergers and acquisitions. In G. Gregoriou \& L. Renneboog (Eds.), International Mergers and Acquisitions Activity Since 1990: Recent Research and Quantitative Analysis (pp. 79-116). Massachusetts: Elsevier 
Meglio, O., \& Risberg, A. (2010). Mergers and acquisitions-Time for a methodological rejuvenation of the field? Scandinavian Journal of Management, 26(1), 87-95. doi: http://dx.doi.org/10.1016/j.scaman.2009.11.002

Metwalli, A. M., \& Tang, R. Y. (2002). Southeast asia: The next M\&A hotspot? Journal of Corporate Accounting \& Finance, 13(2), 39-47.

Metwalli, A. M., \& Tang, R. Y. (2009). Update: M\&A in Southeast Asia. Journal of Corporate Accounting \& Finance, 20(2), 51-60.

Mitchell, W., \& Shaver, J. M. (2002). What Role Do Acquisitions Play in Asian Firms' Global Strategies? Evidence from the Medical Sector, 1978-1995. Asia Pacific Journal of Management, 19(4), 489-502.

Mody, A., \& Negishi, S. (2000). The role of cross-border mergers and acquisitions in Asian restructuring World Bank (Vol. July).

Moeller, S., \& Schlingemann, F. (2004). Are cross-border acquisitions different from domestic acquisitions? Evidence on stock and operating performance for US acquirers. Journal of Banking and Finance.

Morck, R., Shleifer, A., \& Vishny, R. W. (1988). Characteristics of targets of hostile and friendly takeovers Corporate takeovers: Causes and consequences (pp. 101-136): University of Chicago Press.

Myers, S. C., \& Majluf, N. S. (1984). Corporate financing and investment decisions when firms have information that investors do not have. Journal of Financial Economics, 13(2), 187-221.

Nahavandi, A., \& Malekzadeh, A. R. (1988). Acculturation in mergers and acquisitions. Academy of Management Review, 13(1), 79-90.

OECD. (2010). ASEAN countries returning to pre-crisis growth.

Pananond, P., \& Zeithaml, C. (1998). The International Expansion Process of MNEs from Developing Countries: A Case Study of Thailand's CP Group. Asia Pacific Journal of Management, 15(2), 163-184.

Pangarkar, N., \& Lim, H. (2003). Performance of foreign direct investment from Singapore. International Business Review, 12(5), 601-624.

Papadakis, V. M., \& Thanos, I. C. (2010). Measuring the performance of acquisitions: An empirical investigation using multiple criteria. British Journal of Management, 21(4), 859-873.

Parrino, J. D., \& Harris, R. S. (1999). Takeovers, Management Replacement, and PostAquisition Operating Performance: some evidence from the 1980s. Journal of Applied Corporate Finance, 11(4), 88-96.

Pawaskar, V. (2001). Effect of Mergers on Corporate Performance in India. Vikalpa, 26(1), 19-32.

Powell, R. G., \& Stark, A. W. (2005). Does operating performance increase post-takeover for UK takeovers? A comparison of performance measures and benchmarks. Journal of Corporate Finance, 11(1), 293-317.

Qiu, L. D., \& Wang, S. (2011). FDI Policy, Greenfield Investment and Cross-border Mergers. Review of International Economics, 19(5), 836-851.

Rahman, R. A., \& Limmack, R. J. (2004). Corporate acquisitions and the operating performance of Malaysian companies. Journal of Business Finance \& Accounting, 31(3-4), 359-400.

Ramaswamy, K. (1997). The performance impact of strategic similarity in horizontal mergers: evidence from the US banking industry. Academy of Management Journal, 40(3), 697-715. 
Rammal, H. G., \& Zurbruegg, R. (2006). The impact of regulatory quality on intra-foreign direct investment flows in the ASEAN markets. International Business Review, 15(4), 401-414.

Rao-Nicholson, R., \& Salaber, J. (2014a). Cross-border arbitrage and acquisition performance in the Eurozone crisis. Working Paper, University of Bath.

Rao-Nicholson, R., \& Salaber, J. (2014b). Impact of the Financial Crisis on the Performance of European Acquisitions. In Y. Temouri \& C. Jones (Eds.), International Business and Institutions after the Financial Crisis (pp. 73-92): Palgrave Macmillan.

Rao-Nicholson, R., \& Salaber, J. (2015). Impact of Financial Crisis on Banking Acquisitions: a Look at Shareholder Wealth. International Journal of the Economics of Business, 22(1), 87-117.

Schoenberg, R. (2006). Measuring the Performance of Corporate Acquisitions: An Empirical Comparison of Alternative Metrics. British Journal of Management, 17(4), 361-370.

Schweiger, D. M., \& Denisi, A. S. (1991). Communication with employees following a merger: A longitudinal field experiment. Academy of Management Journal, 34(1), 110-135.

Sharma, D. S., \& Ho, J. (2002). The impact of acquisitions on operating performance: some Australian evidence. Journal of Business Finance \& Accounting, 29(1-2), 155-200.

Shelton, L. M. (1988). Strategic business fits and corporate acquisition: Empirical evidence. Strategic Management Journal, 9(3), 279-287.

Sheng, A. (1996). Bank restructuring: lessons from the 1980s: World Bank Publications.

Shimizu, K., Hitt, M. A., Vaidyanath, D., \& Pisano, V. (2004). Theoretical foundations of cross-border mergers and acquisitions: A review of current research and recommendations for the future. Journal of international management, 10(3), 307353.

Slangen, A. H. (2006). National cultural distance and initial foreign acquisition performance: The moderating effect of integration. Journal of World Business, 41(2), 161-170.

Spiegel, M. M. (2009). Monetary and Financial Integration in the EMU: Push or Pull? Review of International Economics, 17(4), 751-776.

Sudarsanam, S. (2003). Creating value from mergers and acquisitions: the challenges: an integrated and international perspective: Pearson Education.

Sufian, F. (2009). Determinants of bank efficiency during unstable macroeconomic environment: Empirical evidence from Malaysia. Research in International Business and Finance, 23(1), 54-77.

Sufian, F., \& Habibullah, M. S. (2012). Globalizations and bank performance in China. Research in International Business and Finance, 26(2), 221-239.

Sun, S. L., Peng, M. W., Ren, B., \& Yan, D. (2012). A comparative ownership advantage framework for cross-border M\&As: the rise of Chinese and Indian MNEs. Journal of World Business, 47(1), 4-16.

Switzer, J. A. (1996). Evidence on real gains in corporate acquisitions. Journal of Economics and Business, 48(5), 443-460.

Thanos, I. C., \& Papadakis, V. M. (2012a). Unbundling acquisition performance: How do they perform and how can this be measured? In D. Faulkner, S. Teerikangas \& R. J. Joseph (Eds.), Handbook of Mergers and Acquisitions. Oxford UK: Oxford University Press.

Thanos, I. C., \& Papadakis, V. M. (2012b). The use of accounting-based measures for measuring M\&A performance: a review of five decades of research. Advances in Mergers and Acquisitions, 10, 103-120.

Travlos, N. (1987). Corporate takeover bids, methods of payment, and bidding firms' stock returns. Journal of Finance, 943-963. 
UNCTAD. (2012). World Investment Report. New York \& Geneva: UNCTAD.

Very, P., \& Schweiger, D. M. (2001). The acquisition process as a learning process: Evidence from a study of critical problems and solutions in domestic and cross-border deals. Journal of World Business, 36(1), 11-31.

Wan, W. P., \& Yiu, D. W. (2009). From crisis to opportunity: Environmental jolt, corporate acquisitions, and firm performance. Strategic Management Journal, 30(7), 791-801.

Wang, Q., \& Boateng, A. (2007). Cross-border M\&As by Chinese firms: an analysis of strategic motivation and performance. International Management Review, 3(4), 19-29.

Yeh, T.-m., \& Hoshino, Y. (2002). Productivity and operating performance of Japanese merging firms: Keiretsu-related and independent mergers. Japan and the World Economy, 14(3), 347-366.

Zhan, J. X., \& Ozawa, T. (2001). Business restructuring in Asia: Cross-border $M$ \& As in the crisis period: Copenhagen Business School Press.

Zollo, M., \& Meier, D. (2008). What is M\&A performance? The Academy of Management Perspectives, 22(3), 55-77.

Zollo, M., \& Singh, H. (2004). Deliberate learning in corporate acquisitions: post-acquisition strategies and integration capability in US bank mergers. Strategic Management Journal, 25(13), 1233-1256. 